\title{
Mainstreaming Green Economy: An Assessment of Private Sector Led Initiatives in Climate Change Adaptation in Ghana
}

\author{
Albert Ahenkan ${ }^{1}$, Jane Osei ${ }^{1} \&$ Erasmus Henaku Owusu ${ }^{2}$ \\ ${ }^{1}$ Department of Public Administration and Health Services Management, University of Ghana Business School, \\ Legon, Ghana \\ ${ }^{2}$ Centre for Climate Change and Sustainability Studies, University of Ghana, Ghana \\ Correspondence: Albert Ahenkan and Jane Osei, University of Ghana Business School, Legon, Ghana. Tel: \\ 233-2-4695-5818; 233-2-6741-5447. E-mail: aahenkan@ug.edu.gh; janeosei@ymail.com; ehowusu@ug.edu.gh
}

Received: February 1, 2018

Accepted: March 2, 2018 Online Published: March 30, 2018

doi:10.5539/jsd.v11n2p77

URL: https://doi.org/10.5539/jsd.v11n2p77

\begin{abstract}
The study examines private sector initiatives and investment challenges in mainstreaming green economy in Ghana. An exploratory study design of qualitative research method was adopted. Due to the level of information required for the study, a purposive sampling technique was employed and a total of twenty-four respondents selected from 8 private sector organisations and some selected government ministries participated in the study. Data collected through in-depth interviews was transcribed, coded and analyzed thematically in line with the objectives and questions of the study. The study found out that green economy initiatives are not well mainstreamed in the private sector. Most companies' involvement in climate change and green economy activities was commonly carried out through corporate social responsibility (CSR). The study further revealed that, government incentives for private sector investments in adaptation are not attractive. The study identified access to finance, poor knowledge base, weak collaborative effort, inadequate incentives, absence of clear-cut government policy and unsatisfactory recognition as challenges facing private sector-led investments in climate change adaptation. The paper recommends the need for government incentives to attract private sector investment, identification of green investment opportunities, collaboration among stakeholders, climate change sensitisation and education among the private sector in order to address the immediate to long-term consequences of climate change in Ghana.
\end{abstract}

Keywords: green economy, Ghana, initiatives, private sector, climate change adaptation

\section{Introduction}

Increasingly, countries are transitioning to green economy as they face pressing economic and environmental challenges (OECD, 2012). The relevance of green economy has been steadily growing over the past few years, and has now emerged as a key topic underpinning both the new policy dynamic promoting sustainable development and increasingly, financial market development. Ghana is not an exception from the countries advancing towards a green economy. The country is making some progress towards its transition to GE through a set of national policies, strategies and programmes in line with sustainable development objectives. The green economy (GE) concept necessitates a shift in recent development conceptualization and contrasts the hazards caused by the untenable methods towards sustainable development (PAGE, 2015). It practically requires sustainable consumption and lifestyle towards economic activities that use natural resources efficiently, improve and reserve environmental quality, and remove social disparities.

GE finds space in Ghana as most of the country's development priorities that are in harmony with the concept's key objectives (PAGE, 2015). Green economy may perhaps be defined as economic system taking into consideration a comprehensive remedial measure en route for fiscal, ecological and societal encounters that halt or reduce economic happenings and growth (Simons, 2010). United Nations Environmental Programme (UNEP) defines GE as an action that brings about an enhancement of human welfare and social justice, though meaningfully minimizing environmental risks and ecological sacrifices (UNEP, 2011). For the purpose of this study, the operational definition of green economy is the actions that have a tendency to make the living conditions of people better through the judicious use of natural resources by way of reducing environmental dangers. 
The emergence of climate change dates back to the 1990s and has since been identified as one of the world's most threatening environment issue (IPCC, 2007). Climate Change signals a 'wake-up call' warning to the effect that, the predominant economic model is not sustainable. It is the disparity in the earth weather condition for a period of time i.e. over 10years. There is no doubt that all countries across the globe are faced with the effects of climate change, however the vulnerability of communities in developing countries is very imperative. Matters of climate change worldwide, are in two segments i.e. mitigation and adaptation. Initially, interventions were focused on mitigation of climate change factors by soliciting technologically advanced countries to minimize their emissions (Seck et al. 2005). However, in recent times, most especially in developing countries, adaptation has been identified as pertinent and balancing response to mitigation (Gagnon-Lebrun \& Agrawala, 2006). Burton et al. (2002) stipulates that adaptation helps to decline considerably the negative effects of climate change and in some cases, improves the beneficiary impacts.

Adaptation has been well-defined by the Intergovernmental Panel on Climate Change (IPCC) as modifications in environmental, societal or financial schemes in responding to real or anticipated climatic provocations and their implications (Smith et al. 2001). The United Nations Global Compact (UNGC) also defines adaptation as 'initiatives and measures to decrease the susceptibility of natural and human systems against real or expected climate change effects (UNGC, 2011). It comprises the adjustments of moderating harm from, or benefiting from, existing climate inconsistency as well as expected climate change. Climate change adaptations have been described by West \& Gawith, (2005) as the events which enable individuals to acclimatise to an extremely challenged weather and climatic disorderliness.

The challenges faced by developing countries due to the impacts of climate change, can directly or indirectly affect businesses. Such challenges may include water shortage, deteriorating agricultural production and deprived health. The government of Ghana has put in place measures to reduce the impacts of climate change in in the country. Nevertheless, significant analyses of these actions are not really targeted at reducing the vulnerability of affected people to climate change (UNGC, 2010). Measures taken are relatively conservative and tend to be more expensive and therefore could not effectively address the impacts that are long-term anticipated.

The World Economic Forum (2013) estimates that by 2020; about $\$ 5.7$ trillion will need to be invested annually in green infrastructure, much of which will be in developing world. This will require shifting the world's $\$ 5$ trillion in business-as-usual investments into green investments, as well as mobilizing an additional $\$ 700$ billion to ensure this shift actually happens. Climate change investment needs are significant in developing countries and at the same time direct government funding is scarce. Terpstra et al. (2013) specifies that, the World Bank's approximation for emerging countries to deal with their present and upcoming climate adaptation requirements is 70 billion USD every year through 2050. The World Bank climate policy initiative's estimation, however, is that, in 2011, only 4.4 billion USD in adaptation finance went to developing countries (Terpstra et al. 2013). This therefore indicates a gap of about 65.6 billion USD per year between what developing countries require.

Private sector participation in adaptation has encountered several challenges. Many enterprises have inadequate knowledge of the anticipated impact particularly in emerging countries where information might not exist. The UNGC (2011) have identified that challenges faced by companies for integrating scientific data is typically covered by a huge geographic zone and lasting tendencies and information relevant to site specific decision-making. Another challenge identified by the PWC (2010) is the lack of clear government policy towards climate change adaptation in Ghana which has led many businesses to choose to "wait and see". One other challenge that is identified by PWC (2010) is the lack of appropriate incentives for the private sector. The benefits of many adaptation measures may be realised later even though investment is required now. However, businesses are focused on short-term costs and profits. According to the UNEP (2016), investments in adaptation have a cost-saving nature hence may not be attractive enough unlike revenue generating investments.

Climate change poses a significant business risk in emerging markets yet few companies have started to recognize climate threats and shift resources accordingly. Although, private sector investment in climate change adaptation has grown steadily in recent years, as companies have had to adapt to the physical risks of climate-related impacts, a large number of companies address these issues from only an infrastructure standpoint without considering the full spectrum of adaptation interventions that could achieve social and economic benefits. Climate Action Network (2013) has indicated that given the diversity of the private sector and of the adaptation challenges facing developing countries, it's not being taken for granted that the private sector will succeed in tackling all kind of adaptation challenges. Private investment activity to date has been unevenly distributed amongst countries and economic sectors, and often it appears not to match developing countries' most pressing adaptation needs. According to Climate Investment Funds (2016), financial constraints and lack of incentives can also be an impediment to private sector participation in adaptation actions. The enthusiasm to deal with climate 
risks via specific technologies or infrastructural changes may sometimes result in neglect of environmental concerns like biodiversity (Næss et al. 2005; Eriksen \& O'Brien, 2007; Eriksen \& Lind, 2009). Thus, adaptation could have an inadvertent adverse effect on both people and the environment as a whole. Due to the fact that, not every adaptation initiative to climate change is good, it is important to assess whether the initiatives by the private sector are good ones hence its sustainability (Eriksen \& O’Brien, 2007).

There has been an emerging literature that emphasizes private sector investments in mitigation and only a little focus of private sector in adaptation especially in emerging countries (Buchner et al. 2011; Kato et al. 2014; UNFCC, 2007). In Ghana some studies on green economy and climate change adaptation have been done, however, little has been researched into the private sector led initiatives on green economy and climate change adaptation. For instance, in the works of Asante et al. (2012) and Bawakyillenuo et al. (2014) on climate change adaptation, the focus was on the agricultural sector. The study examines private sector initiatives and investment challenges in mainstreaming green economy in Ghana. The research seeks to create an evidence base to build the private sector case for action on climate resilience and also provide guidance to policymakers and private sector on the need to invest in climate interventions and projects that will enhance adaptation and options that enable businesses to adapt to climate change and also help communities to adapt.

\section{Brief Literature Review}

\subsection{The Concept of Green Economy}

The Green Economy (GE) concept entails a paradigm shift in contemporary development thinking, taking into account the dangers posed by the unsustainable approaches to development in the past decades. The novel policy wave far-reaching both advanced and emerging countries is the progression towards green economies. This concept is an invention of the advanced countries and can be drawn back to the 2008 economic crises. It came to the realization that neither the augmented greenhouse gases nor the global economic crises possibly will be overturned with the present manufacturing and production systems, which had a rising impact on the environment. In pursuit to re-invigorate economic growth, global leaders saw the need to find a solution to the economic crisis that served as drivers of the global green economy transition, including energy and climate change (Atkisson, 2012). "Green economies" have been defined by Simons (2010) as economic schemes that considers a comprehensive remedial or corrective action incorporating economic, environmental (including ecological) and social challenges that halt or decrease economic activities and growth. The desire to improve the well-being of people through combatting climate change, energy uncertainty and environmental variability is dominant to the "green economy" (Kaggwa, Mutanga Savious, Nhamo, \& Simelane, 2013).

\subsection{The Concept of Climate Change Adaptation}

Climate change adaptation has been defined by a representative group of the United Nations Global Compact as 'initiatives and actions to decrease the vulnerability of natural and human arrangements contrary to real or anticipated climate change consequences' (UNGC, 2011). There is no doubt that all countries are faced with climate change effects, however the vulnerability of communities in developing countries is very imperative. The emergence of climate change dates back to the 1990s and has since been known as one of the world's most threatening environment (IPCC, 2007). Adaptation on the other hand is defined by the "Intergovernmental Panel on Climate Change (IPCC)" as alterations in environmental, societal or financial systems in response to real or anticipated climatic stimuli and their effects (Smith et al. 2001). It comprises changes that will help restrain the damage or advantage from present climate inconsistency and also expected climate change.

\subsection{Theoretical Framework}

This research is hinged on the framework of the stakeholder theory and the rational actor model. According to Mitchell et al. (1997) and Grimble (1998), stakeholders are the actors who have a stake in relation to a specific issue and in this context, climate change because they may either influence or be affected by it (Freeman, 1984). There are two perspectives of stakeholders i.e. mandatory and permissive stakeholders. Mandatory stakeholders are those directed by authority or law to be stakeholders in a policy or governmental actions i.e. the public sector in the case of climate change adaptation. Permissive stakeholders are in two forms namely interest wielders and interest advocates. Interest wielders are those who are directly affected by a policy and are permitted to participate in policy process whereas interest advocates are those stakeholders who are purported to fight for the interest wielders who cannot fight for themselves (Ahenkan et al. 2013). In this case, the private sector in climate change adaptation are permissive stakeholders who are not mandated but can be involved in one way or the other as the effects may directly or indirectly affect their business. In the quest to address the problem of climate change, all stakeholders must be involved. However, the private sector is seen as a rational actor under the rational actor model which was proposed by neo-realists under the rationality theory (Aniagyei, 2015). In view 
of this, the conduct of the private sector in relation to climate change adaptation is explained by the rationality theory as carefully considering their interests by doing a cost benefit analysis before undertaking any adaptive action.

\subsection{Conceptual Framework}

In order to better explain the stakeholder theory relating to climate change adaptation, a conceptual framework is presented in Figure1. This framework highlights a number of stakeholders, both mandatory and permissive forming allegiance to respond to climate through adaptation means. The framework depicts private sector as a permissive stakeholder and affirms a collaborative stakeholder role towards building climate change adaptation. It reaffirms the stakeholder model of corporation where every stakeholder is brought on board to help overcome the pressures of climate change through adaptation.

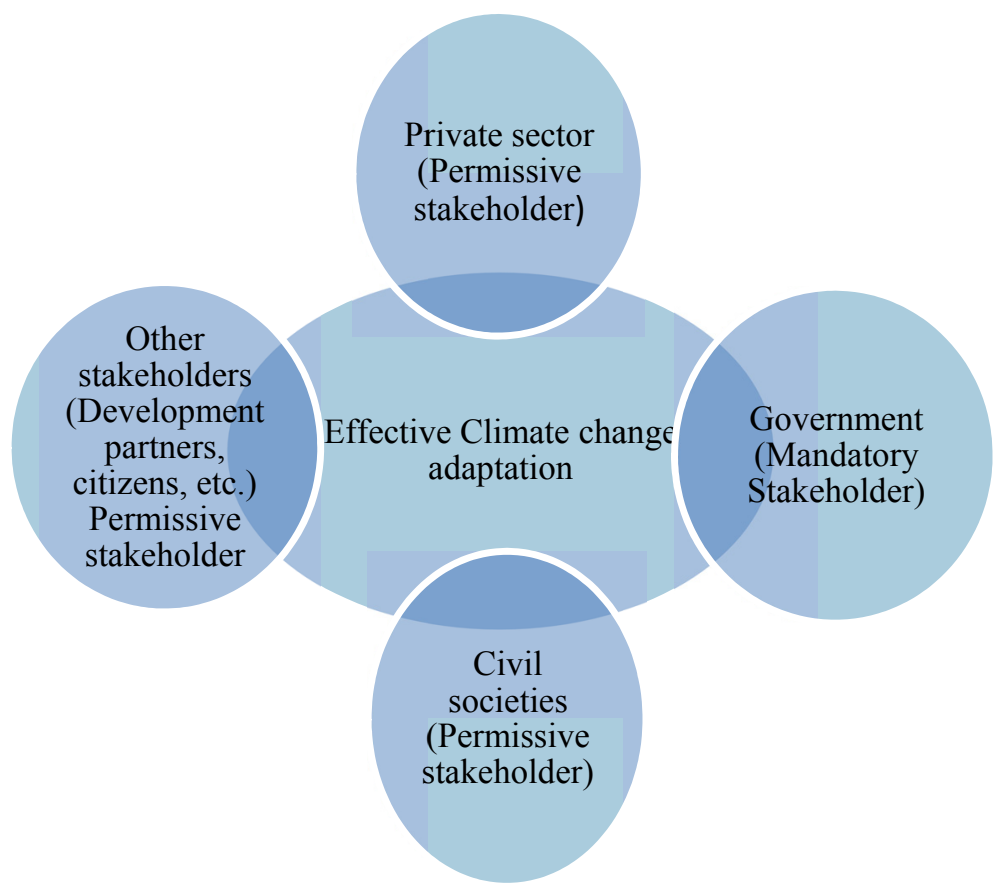

Figure 1. The stakeholder model of corporation above represents this idea

Source: Researchers conceptualisation (2017)

\section{Methodology}

The study adopted a qualitative approach which gives a social representation rather than a mere statistical data (Cresswell, 2013). In order to achieve the purpose of the study, an exploratory approach was employed. An exploratory approach is defined as the preliminary research into a hypothetical or theoretical idea (Kowkzyk, 2015). This is where a researcher has an idea or has observed something and seeks to understand more about it.

The population for this study comprises of the top managers and environmental officers of the selected companies under the umbrella of Association of Ghana Industries (AGI). In all a total of twenty-four respondents were selected from eight private sector organisations in Accra. The study adopted a purposive sampling technique to select the respondents for the study (Neuman, 2011 and Zikmund, 2003). The respondents were selected purposively due to their knowledge and role in these organisations. The respondents were selected from AGI, Ecobank Ghana Limited, Unilever Ghana Limited, Guineas Ghana Limited, Newmont Ghana Limited, African Energy Consortium Limited, Tullow Ghana, Coca-Cola Ghana limited. In addition, in-depth interviews were also conducted with policy makers and implementers from the Ministry of Environment, Science, Technology and Innovation as well as the Environmental Protection Agency.

Babbie (2013) has asserted that, it is ideal for researchers to adopt in-depth interviews as it helps to avoid lead on situations. The adoption of in-depth interviews helped to gather detailed information about private sector's contribution to climate change adaptation and green economy in Ghana. The interview was guided by an 
unstructured interview guide with open-ended questions. The duration of each interview was between forty-five to sixty (45-60) minutes. It has been recommended by Fraenkel and Wallen (2000) that researchers should give assurance of highest confidentiality for data provided by respondents for any study. In view of this, people requested to participate in the study were asked for their informed consent before they were interviewed. addition to the interviews, field observations were made in order to provide supporting evidence of the various initiatives and projects undertaken by these companies.

A systematic research of the secondary data was undertaken prior to conducting the primary research. The secondary information provided a useful background and identified key questions and issues needed to be addressed by the research. A variety of secondary sources of data used included journal articles, annual reports, magazines, newspapers, periodicals and business reports. Relevant literature on climate change adaptation and green economy were reviewed for deeper insight into the underlying concepts of the study. Data analysis in this research consisted of 'three concurrent flow of activity: data reduction, data display and conclusion drawings or verifications' (Miles and Huberman, 1994: 11).

\section{Results and Discussions}

\subsection{Private Sector Initiatives towards Climate Change Adaptation in Ghana}

The study reveals that the private sector organisations in Ghana engage in different kinds of adaptation and green initiatives while others also were not involved at all. Most of these are carried out through corporate social responsibilities. Over $80 \%$ of the initiatives expressed by respondents as adaptation initiatives were mainly mitigation measures with little focus on adaptation. This confirms the findings from literature that most private sector organisations focus is on mitigation actions. Companies that were unable to specify initiatives or projects they have invested in are currently having CSR projects that have the adaptation bit in it. In line with this finding, Levy (2015) concluded that CSR is not a likely remedy to the crises of climate change.

Some of the private sector initiatives identified included green initiatives, award systems, environmental and risk policy and advocacy. With respect to environment and risk policy, findings revealed that about $95 \%$ of the private sector organisations do not have a clear-cut policy on climate change adaptation and green economy. However, the few who engage in climate change adaptation and green economy have an environment and risk policy that factors issues of climate change and its adaptation bit into it. It is also evident from findings that, though some companies are unconcerned, others give recognition to its impact and the changing environment. Organisations do not pay much attention to establishing a climate change adaptation policy. Some issues raised by respondents were the fact that, government does not have a clear-cut policy direction which the private sector can draw their policies from. One respondent from the oil and gas sector passed a funny but sensitive comment. He asserted that;

"My dear did you by any chance hear of anything climate change or green economy in the recent budget read by the Finance Minister? So, if government is not even considering it, why will a profit-making organization like mine consider a policy on it? We do not have a policy on climate change adaptation but we do some corporate social responsibilities that have probably a bit of adaptation in it. I don't think even the government will expect me to have a policy for only climate change. When you went to the companies, how many of them did you find with climate change adaptation policy. Well I am sure, some may have an environmental and sustainability policy may be because of the government environment regulatory bodies but how strong are these institutions. So, you see, it's about time the governments take the lead in some of these things so the private sector can follow."

It is evident from findings that most of the private sector organizations do not have a clear policy on mainstreaming climate change adaptation in their activities. Over $80 \%$ are not aware of government policies and incentives towards climate change mitigation and adaptation in Ghana. In terms of advocacy, it was revealed that $60 \%$ of the companies advocate for the participation of private sector investment in adaptation. This is done through workshops, seminars and public lectures. Most of them do not have specific projects but rather using other medium to sensitize the public against the impact of climate change adaptation. A respondent from the AGI for instance said;

"We discuss with our members about climate change and even though we do not directly involve in adaptation projects, we organise workshops for our members to discuss on how to improve their environment compliance systems especially for those in the agriculture sector. We have an award system that includes categories for best environmental compliance company, best manufacturing company and so on. This is to encourage members who already have such initiatives to do more and for those who do not involve to get involved. Our members who receive such awards are very much encouraged because 
it gives them some kind of recognition."

On the other hand, $50 \%$ of the companies had specific projects which include waste reduction, reforestation, biodiversity, water stewardship, revegetation of buffer zones, crises management, recovery of biogas from waste water treatment etc. The EPA indicated that it engages with the private sector through activities such as an award system geared towards motivating companies to be environmentally responsible and also initiate adaptation projects. Some categories of the award system include; best environmental compliance company, best manufacturing company etc. Figure 2 presents some of the private sector initiatives in climate change.

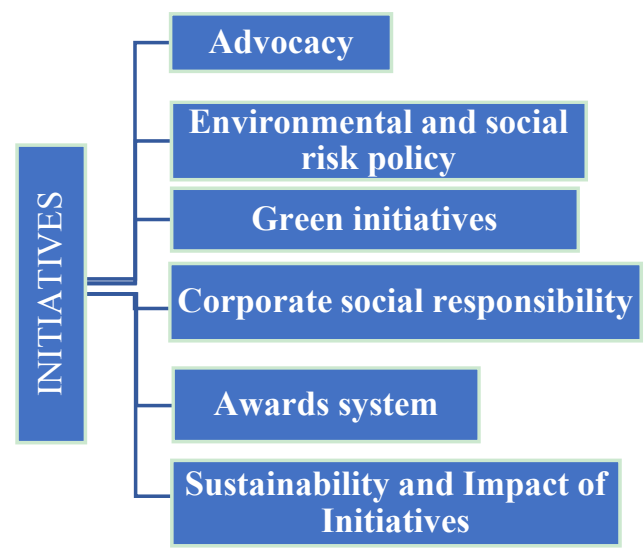

Figure 2. Summary of initiatives identified

\subsection{Drivers of Private Sector Initiatives in Climate Change adaptation}

The second objective was to find out the drivers of private sector investment in adaptation in Ghana. Findings from the study revealed a number of factors motivating the private sector-led initiatives in climate change adaptation and green economy.. Almost all companies interviewed were concerned about the risk climate change poses to their business. This finding is affirms Agrawala et al. (2011) and Kahneman \& Tversky (1979) in their "prospect theory" which indicates that decisions can sometimes be made under conditions of risk.

It was also revealed that, most companies see investment in climate change adaptation as corporate social responsibility. For instance, a respondent from the financial sector said;

"We do a lot of CSR activities which have climate change adaptation piece in it. For instance, we provided a solar pump for the people of Kojo Ashong and have also provided a solar system for a clinic within the Ga Rural area recently. I can even show you pictures of these projects and those we have done in the past. The projects though not categorised as a climate change adaptation project, has improved the lifestyle of people and served as a supplementary to the use of energy so in a way we have initiated some adaptation projects but like I said we are mainly project financiers."

Also, findings indicate opportunities for partnerships as an encouragement for private sector investment in climate change adaptation and green economy. Respondents advocated for more partnerships with government, donor agencies and development partners. For instance, a respondent from the mining sector said;

"We look forward to partnering with government and other Non-Governmental Organisations but we are also particular about the feasibility of the kind of adaption initiative. There should be an attraction from partnership. Projects under partnerships must be viable and standardised. We do not accept to finance just any project and this is why we hire experts to examine the viability of projects that we finance. It's a rigorous process in order to be sure that we are investing in the right projects"

Other incentives identified by the respondent included; motivation to do something good, project viability and high cost of production due to climate change impacts. Collectively, respondents have expressed their concern for government to provide attractive incentives for private sector involvement in climate change adaptation. This is in line with the findings of OECD mentioned in the analysis above. 


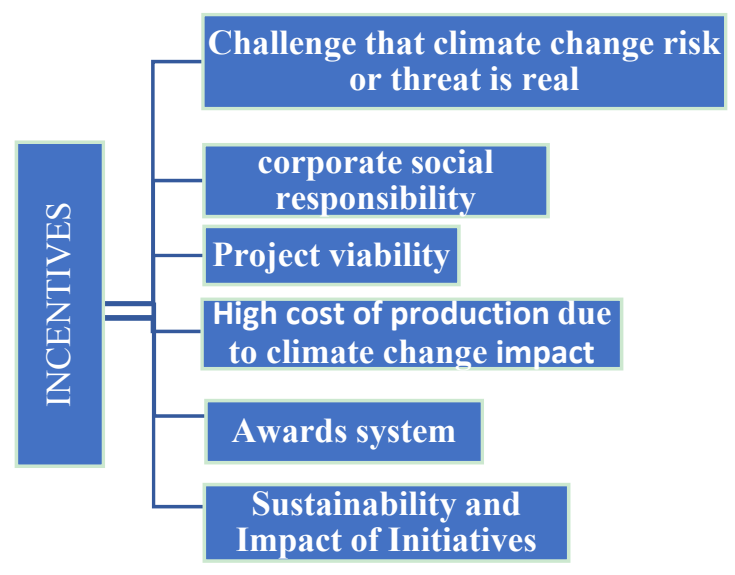

Figure 3. Summary of incentives identified

The research also felt the need to involve policy makers and implementers about the available incentives for the private sector participation in climate change in Ghana. It was revealed that, a number of incentives are available for private sector initiatives in climate change. Unfortunately, over $80 \%$ of the private sector are not aware of the available incentives by government to encourage private sector investments in climate change actions. Respondents from MESTI and EPA also highlighted the availability of some policies opportunities for private sector involvement in climate change to include; the Environment Fiscal Reform Policy, Nationally Appropriate Mitigation Action (NAMA) Investor Guide, Green Climate Fund, Clean Development Mechanism, REDD+ (reducing emission through deforestation and land degradation) among others.

Concerns raised were that, irrespective of the availability of all these policies and incentives to the private sector, only a few are aware and benefit from it. Respondents argued that, the private sector in general are profit oriented hence anything that will not inure to their immediate benefit is not significant to them. Respondent further indicated that, efforts to create awareness across all sectors have not really been successful.

This is because workshops, seminars and other relevant meetings organised for private sector in order to be informed about government policies and incentives in this direction have witnessed minimum attendance by the private sector. The Private Enterprise Federation (PEF) being the focal point for the private sector is constantly fed with information in this regard and made part of policy making process. It was clear that although most private sector organisations focus on mitigation activities, most of the activities have co-benefits of adaptation.

\subsection{The Challenges of Private Sector-Led Initiatives in Climate Change Adaptation}

Access to finance is a challenge in Ghana. It is obvious from findings that, in line with (Agrawala et al. 2011; Buchner et al, 2011; Kato et al. 2014; UNFCCC, 2007), there is low participation of private sector in climate change adaptation and green investment due to financial challenge. Private investment is crucial in climate change adaptation. The involvement of private sector in climate change is important for government but efforts to get their participation in adaptation are challenged by lack of funds and access to credit. Unfortunately, most of the financial institutions are not interested in funding climate change actions. This is because adaptation benefits are long-term and the private sector being profit oriented do not feel the need to invest.This therefore makes relevant the assertion by (Acclimatise, 2009; Long, Zadek \& Wickerham, 2009; PwC, 2010) that, every country's accomplishment in adaptation is reliant mainly on the choices made within the private sector.

Adding to the already existing challenges identified by the works of PWC (2013), IFC (2011), UGNC et al. (2011) Terpstra et al. (2013) and CDKN (2015), this study has identified some constraints that are rare in literature. These include; financial constraints which most of the respondent see as a major challenge to their investment in climate change and green economy. Issues raised included cost of acquiring license for carrying out some adaptation projects and the absence of tax incentives. This is in line with CDKN (2016) who identified lack of finance as one of the challenges to climate change adaptation. One of the key concerns raised by a respondent from the mining sector is that, the company cannot do much in financing climate change adaptation due to lack of finance. In his words, he said;

"It would have been good for us to do much regarding adaptation but we can only do so little. Doing so 
little, if you go out there and you tell people you want to do energy and climate change, people go like wow. You create a different interpretation, now everybody thinks it's you and the government so they going to sell all their climate issues so there is that high expectation to come and do your bit, so sometimes you are mindful of how you articulate it to people and you don't get bombarded with commitments"

Concerns raised suggest that, a financial scheme be set up by development partners, donor agencies and other key stakeholders to implement climate change actions. This will help private sector to get involved in climate change adaptation.

Another challenge identified is the poor knowledge base of climate change adaptation. Findings indicate that most of the companies do not know what climate change adaptation is about and interpreted their mitigation measures to be adaptation initiative. This was confirmed by some respondents as they identified it as one of the challenges to their investment in the study area. The challenge according to respondent from the mining sector is quoted below;

"The challenge basically is the social i.e. how people seek to understand what climate change is. They do not have the basic understanding especially the adaptation piece so we have the duty to educate them and I think that is the basic challenge for us. For instance, the communities in which we have done a few adaptation projects have not really appreciated the impact because they do not understand anything. But we will gradually get there."

Findings further indicate that about $90 \%$ of the companies are not aware of what they stand to gain from investing in climate change adaptation hence do not find investing profitable. It is therefore highly recommended that, public education on climate change and green economy should be intensified across all sectors. The importance of private sector engagement in adaptation must be clear to companies. Despite the level of climate change education in the country, most private sector companies are not aware of its implications on their business and the need for their involvement. Measures taken by private sector have been focused on mitigation with limited attention paid to adaptation. It is therefore important for government to enhance adaptation education among the private sector

Another concern raised by respondents is the lack of clear policy from government. This issue cuts across all respondents interviewed and this was expressed with sentiments. According to respondents, the absence of a clear policy direction and vision strategy from government affects their interest to invest. A respondent from the mining sector asserted;

"The government does not have a clear policy direction and vision strategy that we can follow to support. Knowing what government is doing will guide the private sector as to which adaptation need to implement and what directions to take. And you know a lot of these policies are probably sitting on the ministries table. Yes, they are because we have heard time without number that government is coming up with a policy. There have been several stakeholders meeting we have attended to come up with a policy but we go sit and talk plenty yet no proper policy on climate change has come out. If really the private sector can be actively involved then government must sit up."

The policy environments in which companies operate have influence on their corporate decision. Government should have a clear-cut policy which will guide the private sector to identify areas that require adaptation needs. Some of these policies can serve as an economic incentive for the private sector. As suggested by PWC (2010), the absence of a clear policy direction makes the private sector lay back.

Findings also reveal unattractive government incentives as one of the challenges to private sector investment. Respondents expressed that the absence of government incentives demoralises their desire to do more. The few initiatives they have rolled out have only a business case for their investment. Another challenge was the weak collaborative effort among other stakeholders. These challenges influence the decisions of private sector to initiate measures to adapt to climate change adaptation. Figure 4 indicates some of these challenges. 


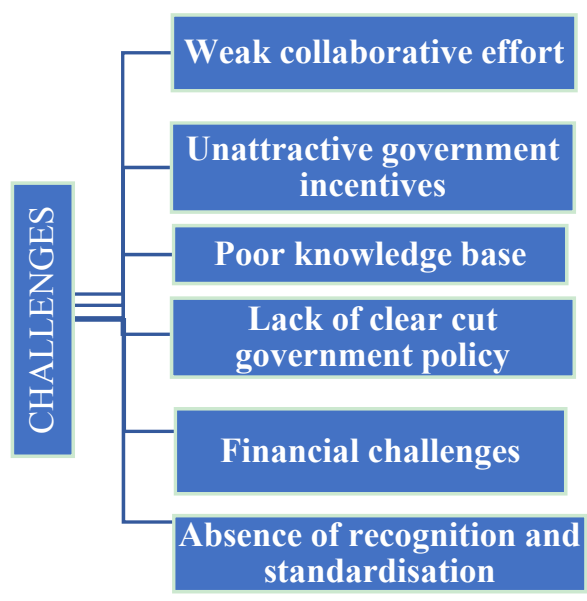

Figure 4. Summary of some private sector challenges

\section{Conclusion}

The need for private sector investment in climate change and green economy has been established. The importance of the role of the private sector is evident from the study and from experience of private sector organisations in adaptation projects through their CSR activities. A successful private sector engagement in adaptation will catalyse greater investment required in Ghana to reduce the climate change vulnerabilities among the people. The study reveals that though the private sector is willing to invest in climate change adaptation and green economy, the knowledge of the available opportunities is limited and the incentives from the government not attractive. A number of drivers of private sector participation in climate change adaptation have been identified. These include high cost of production due to climate change risk, the reality of climate change risk, motivation to do something good, project viability among others. The study identified a number of challenges affecting the private sector led investments in adaptation actions in Ghana. These include lack of access to finance, poor knowledge base, weak collaborative effort, inadequate incentives, absence of clear-cut government policy and unsatisfactory recognition as challenges facing private sector-led investments in climate change adaptation. There is a need for the private sector to be more engaged in identifying climate change risks, opportunities response measures, and adaptation, and to prioritize them in Ghana. This will help to stimulate and accelerate the much needed climate-resilient development in Ghana. There is the need to incentivise the private sector to participate through access to finance, tax incentives, stakeholder engagement, collaboration and effective change sensitisation and education.

\section{References}

Acclimatise. (2009). Building Business Resilience to inevitable Climate Change. Carbon Disclosure Project Report. Global Mining. Acclimatise, Oxford.

Agrawala, S., Carraro, M., Kingsmill, N., Lanzi, E., Mullan, M., \& Prudent-Richard, G. (2011). Private sector engagement in adaptation to climate change: approaches to managing climate risks. OECD Environment Working Papers, No. 39, OECD Publishing. https://dx.doi.org/10.1787/5kg221jkf1g7-en

Ahenkan, A., Bawole, N., J., \& Domfeh, K. A. (2013). Improving citizen's participation in local government planning and financial management in Ghana: A stakeholder analysis of the Sefwi Wiawso Municipal Assembly. Journal of public administration and governance. https://doi.org/10.5296/jpag.v3i2.3782

Aniagyei, J. (2015). The concept of climate change management: An analysis of the Kyoto Protocol.

Atkisson, A. (2012). Life beyond growth. ISHES, Tokyo.

Babbie, E. R. (2013). The basics of social research. Cengage Learning.

Bawakyillenuo, S., Yaro, J. A., \& Teye, J. (2014). Exploring the autonomous adaptation strategies to climate change and climate variability in selected villages in the rural northern savannah zone of Ghana. Local Environment: The International Journal of Justice and Sustainability. Retrieved February 10, 2017, from http://www.tandfonline.com/doi/abs/10.1080/13549839.2014.965671\#.VbJCKPm4G

Buchner, B., Falconer, A., Hervé-Mignucci, M., Trabacchi, C., \& Brinkman, M. (2011). The landscape of climate 
finance. Climate Policy Initiative, Venice, 27.

Climate Action Network. (2013). Climate change adaptation and the role of the private sector: Creating effective tools for private sector engagement. Climate Action Network Europe.

Climate Development and Knowledge Network. (2016). Feature: Making the business case for private sector investment in climate compatible development; Private sector engagement in Climate Compatible Development (CCD) in Bangladesh.

Climate Investment Fund. (2016). Private Sector Investment in Climate Adaptation in Developing Countries: Landscape, Lessons Learned and Future Opportunities.

Creswell, J. W. (2013). Research design: Qualitative, quantitative and mixed methods approaches (3rd ed.). Thousand Oaks, CA: Sage Publications Incorporated.

Fraenkel, J. R., \& Wallen, N. E. (2000). How to design and evaluate research in education (7th ed.). New York: McGraw-Hill Higher Education.

Freeman, R. E. (1984). Strategic management: A stakeholder approach. Boston [Mass.]; London: Pitman.

Freeman, R. E. et al. (2010). Stakeholder theory, the state of the art.

Gagnon-Lebrun, F., \& Agrawala, S. (2006). Progress on adaptation to climate change in developed countries: an analysis of broad trends. Paris: OECD.

Intergovernmental Panel on Climate Change. (2007a). climate change 2007: impacts, adaptation and vulnerability. Contribution of working group II to the fourth assessment report of the intergovernmental panel on climate change.

Intergovernmental Panel on Climate Change. (2007b). IPCC Fourth Assessment Report: Summary for Policymakers of the Synthesis Report. $\quad$ Retrieved from http://www1.ipcc.ch/pdf/assessment-report/ar4/syr/ar4_syr_spm.pdf

International Financial Corporation. (2011). Climate Finance: Engaging the Private Sector; A background paper for "Mobilizing Climate Finance," a report prepared at the request of G20 Finance Ministers. Washington, D.C. $\quad$ Retrieved from http:/www1.ifc.org/wps/wcm/connect/5d659a804b28afee9978f908d0338960/ClimateFinance_G20Report. pdf? MOD=AJPERES

Kato, T., Ellis, J., Pauw, P., \& Caruso, R. (2014). Scaling up and replicating effective climate finance interventions. Climate Change Expert Group Paper No 2014(1). OECD and IEA, Paris. https://doi.org/10.1787/5js1qffvmnhk-en

Levy, L. D. (2015). Why corporate sustainability won't solve climate change. Retrieved from $\mathrm{http}$ //theconversation.com/why-corporate-sustainability-wont-solve-climate-change-51439

Næss, L.O., Bang, G., Eriksen, S., \& Vevatne, J. (2005). Institutional adaptation to climate change: Flood responses at the municipal level in Norway. Global Environmental Change, 15(2), 125-138. https://doi.org/10.1016/j.gloenvcha.2004.10.003

OECD. (2012). Green Growth and Developing Countries; A Summary for Policy Makers.

PAGE. (2015). Ghana's Transition to a Green Economy: A Stocktaking Report.

Price Waterhouse Coopers. (2013). Stimulating private sector engagement and investment in building disaster resilience and climate change adaptation; Recommendations for public finance support pg. 9

Seck, M., Mamouda, M., \& Wade, S. (2005). Case Study 4: Senegal adaptation and mitigation through "Produced environments": The case for agriculture intensification in Senegal. IDS Bulletin, 36(4), 71-86. https://doi.org/10.1111/j.1759-5436.2005.tb00235.x

Terpstra, P., McGray, H., \& Ofsetedahi, A. (2013). Adapting to Climate Change Private Sector's Role: World Resources Institute. Retrieved from https:/www.wri.org/blog-tags/8641?page=1

The World Economic Forum (2013). The Green Investment Report The ways and means to unlock private finance for green growth, World Economic Forum, Geneva, Switzerland. pp 38.

United Nations Environmental Programme (UNEP). (2011). Towards a Green Economy: Pathways to Sustainable Development and Poverty Eradication. Nairobi: UNEP.

United Nations Framework Convention on Climate Change (UNFCCC). (2011). Report of the Conference of the 
Parties on its sixteenth session, held in Cancun from 29 November to 10 December 2010. Decision 1/CP, Paragraph 18. Retrieved from http://unfccc.int/resource/docs/2010/cop16/eng/07a01.pdf

United Nations Global Compact, Oxford Group \& Caring for Climate. (2010). Retrieved from http://unglobalcompact.org/docs/issues_doc/Environment/climate/CARING_FOR_CLIMATE_STATEMEN T_pdf

\section{Copyrights}

Copyright for this article is retained by the author(s), with first publication rights granted to the journal.

This is an open-access article distributed under the terms and conditions of the Creative Commons Attribution license (http://creativecommons.org/licenses/by/4.0/). 